\title{
Otolith morphometry provides length and weight predictions and insights about capture sites of Prochilodus lineatus (Characiformes: Prochilodontidae)
}

\author{
Herick Soares de Santana ${ }^{1,2}$, Amanda Cantarute Rodrigues ${ }^{1}$ \\ and Carolina Viviana Minte-Vera ${ }^{1,3}$
}

Here we choose the sábalo Prochilodus lineatus, to answer the following questions: How the otolith length and weight are correlated to fish measurements (length and weight)? How reliable are the otoliths measurements to predict the length and age of $P$. lineatus? Finally, we propose predictive equations of the length and weight of the fish using length and weight of the otolith. The otoliths were sampled from individuals collected in the Upper Paraná River floodplain during 2012 and 2013 years. The relationships among the otolith measurements and both length and weight of the fish were performed using linear regressions. To test whether the length and weight of the otolith differ between the sampled sites, Variance Analysis was performed. Finally, we made analysis of Kruskal-Wallis to verify if the measurements obtained through the otoliths could be used to distinguish the age of the fish. We demonstrate that the length and weight of the otolith are good proxies to predict the length and weight of the fish. Although some ages were statistically different, this result does not support the idea that the age of the fish can be accurately inferred only using otolith measures.

Keywords: Age of fish, Lapillus, Migratory fish, Otolith description, Sábalo.

Neste trabalho o curimba Prochilodus lineatus foi utilizado para responder as seguintes questões: Como o comprimento e o peso dos otólitos são correlacionados com o comprimento e o peso do peixe? Até que ponto as medidas dos otólitos são confiáveis para predizer a idade do P. lineatus? Finalmente, nós propomos equações preditivas do comprimento e peso do peixe utilizando o comprimento e o peso do otólito. Os otólitos foram amostrados de indivíduos coletados na planície de inundação do alto rio Paraná durante os anos de 2012 e 2013. As relações entre as medidas dos otólitos e o peso e comprimento do peixe foram verificadas utilizando regressões lineares. Para testar se o comprimento e o peso do otólito diferem entre locais foram utilizadas Análises de Variância e para testar se as medidas dos otólitos são suficientes para distinguir as idades foram utilizados testes de Kruskal-Wallis. Nós demonstramos que o comprimento e o peso do otólito são bons preditores do comprimento e peso do peixe. Embora algumas idades foram estatisticamente diferentes entre as medidas dos otólitos, esse resultado não suporta a ideia de que a idade do peixe pode ser inferida de forma acurada somente utilizando as medidas dos otólitos.

Palavras-chave: Curimba, Descrição de otólitos, Idade de peixes, Lapillus, Peixes migradores.

\section{Introduction}

Historically, otoliths have been mainly used for age and growth studies, with a focus on inputs for stock assessments (Chris-Francis, Campana, 2004) and to produce basic information about growth parameters of fish stocks. Due to their chemical and morphological proprieties, otoliths, however, have been more recently used to separate populations of the same species (Campana et al., 1999; Radhakrishnan et al.,
2012; Škeljo, Ferri, 2012), and even species identification. This is particularly relevant in archeology, paleontology and animal diet studies, since otoliths are usually preserved in the fossil record and frequently found in stomach contents of several species (Fitch, Brownell, 1968; Van Neer et al., 2002; Reichenbacher et al., 2007).

The taxonomic characteristics of otoliths have been explored mainly for the marine environment, and various species guides describe in detail the morphology of otoliths

${ }^{1}$ Programa de Pós-Graduação em Ecologia de Ambientes Aquáticos Continentais. Universidade Estadual de Maringá. Av. Colombo, 5790, 87020-900 Maringá, PR, Brazil. (HSS) herick.bio@gmail.com, Dhttps://orcid.org/0000-0001-8138-5261 (corresponding author), (ACR) amandacantarute@gmail.com

${ }^{2}$ Departamento de Áreas Acadêmicas. Instituto Federal de Goiás. Campus Águas Lindas de Goiás, Rua 21, Jardim Querência, 72910-733 Águas Lindas de Goiás, GO, Brazil.

${ }^{3}$ Inter-American Tropical Tuna Comission, 92037-1509 La Jolla, CA, USA. cminte@iattc.org 
(Tuset et al., 2008). In freshwater fish, especially for those descended from the Ostariophysi lineage, the sagitta otolith is reduced and is not used for age and growth studies, while pairs of asteriscus and lapillus otoliths are more developed and have distinctive characteristics for each species. In this sense, the morphological characterization of the otolith can be critical in studies of trophic webs, assisting in the identification of prey through the otoliths found in the stomach contents, and allowing the reconstruction of past fauna compositions (Reichenbacher et al., 2007).

The main method to perform age inferences through otolith is by reading the growth rings produced periodically. This can be done in several ways, for example, cutting the otolith in different planes or performing readings on the entire otolith (see Secor et al., 1991). However, age estimates are usually difficult to obtain using these structures, due to the high cost equipment and skills necessary to process the otolith and make precise and accurate readings (Ilkyaz et al., 2011).

An alternative to minimize these difficulties is to obtain the age using only the morphometry and the weight of the otolith, so that the otolith does not need to be processed. To obtain the age in a reliable manner, there must be a strong correlation between fish growth and growth of the otolith and, furthermore, a set of fish shall be aged using annulus counts. The otoliths, in contrast to other bones, only have accretion processes; this tends to result in positive relationship between the growth of the otolith and fish growth (Battaglia et al., 2010; Humston et al., 2015). Thus, predictive models that use the weight or any other measure of the otolith could provide cheaper methods to estimate age, as they do not require specialized reader skills nor expensive processing of the otolith (Chris-Francis et al., 2005).

The sábalo Prochilodus lineatus (Valenciennes, 1837) is an important commercial species distributed abundantly in South America, belongs to the Prochilodontidae family, which is characterized mainly by its migratory behaviour (Agostinho et al., 2000). This species has suffered severe population depletions, mainly due to the construction of reservoirs that block access to spawning and nursery grounds (Agostinho et al., 2007; Barletta et al., 2010; Fontes-Júnior et al., 2012). Prochilodus spp. forms the foundation of artisanal fisheries for several basins in South America (Welcomme, 1979; Harvey, Carolsfeld, 2003; Baigún et al., 2013). For example, P. lineatus is one of the most important species for fisheries in the Itaipu Reservoir (Gomes, Agostinho, 1997; Okada et al., 2005) and contributed almost $90 \%$ ( 295 tons) of the total freshwater fishes of the Argentinean catch between 1994 and 2010 (Iwaszkiw, Lacoste, 2011).

One way to provide solutions to solve these problems is to better understand population aspects so that accurate and reliable information is generated and encourage more complex assessments of fish stocks. Therefore, in this study, we aimed to (1) describe the morphology of the lapillus otoliths of Prochilodus lineatus and (2) to provide morphometric details of the lapillus otoliths and addressed the following questions: How the otolith length and weight are correlated to fish measurements (length and weight)? How reliable are the otoliths measurements to predict the length and age of $P$. lineatus? Finally, we propose predictive equations of the length and weight of the fish using length and weight of the otolith. The otolith lapillus was chosen due to the previous results indicating that this is the best pair of otoliths for age checks in Prochilodus lineatus. Thus, a better understanding of its structure is essential for population studies as well as studies of species identification and reconstruction of trophic webs.

\section{Material and Methods}

Study area and sampling. The study covered ten sampling stations located in the Upper Paraná River Floodplain (Fig. 1): three rivers (Paraná, Baía and Ivinhema), four open lakes (lagoa do Guaraná, lagoa dos Patos, lagoa das Garças e ressaco do Pau Véio) and three closed lakes (lagoa Ventura, lagoa do Osmar e lagoa Fechada). This set of sites comprises the main growth and breeding sites of $P$. lineatus, since the population of this species has a marked spatial structure (Santana, Minte-Vera, 2017).

Five samplings were performed: June, September and December 2012 and March and June 2013 using 11 sizes of mesh gillnets $(2.4,3,4,5,6,7,8,10,12,14$ and $16 \mathrm{~cm}$, between opposite knots). Each gillnet remained in the water for 24 hours at each sample site and were revisited every 8 hours. Additionally, in the lakes associated with each river, trawls were performed. Before extraction of the otoliths, the standard length ( $\mathrm{mm}$ ) and total weight $(\mathrm{g})$ of fish were obtained. The otoliths were extracted using a cross-section cut on the dorsal surface of the fish's head to expose the inner ear where the otoliths are inserted (VanderKooy, Guindon-Tisdel, 2003).

Otolith morphology and morphometry. The morphological description of lapillus otoliths was defined according to the terminology adopted by Assis (2005). This author proposes an interesting discussion on the morphological importance of otolith lapillus for teleost fish, both in relation to identification and systematics. Photographs of the otoliths were taken using a scanning electron microscope (SHIMADZU; Model: SS550). Lapillus is the most robust pair of otoliths of P. lineatus, because sagitta is very small and the asteriscus, although it is the largest, is more fragile. Therefore, lapillus is more likely to be found intact in stomach contents and fossil record.

To make predictions about the length and weight of the fish, we took the length (LO) and weight ( $\mathrm{WgO})$ of lapillus otolith. These two measurements were made because it has already been demonstrated that the length and weight of otolith are the measures most correlated to somatic growth (Megalofonou, 2006; Jawad et al., 2011; Zan et al., 2015). The measures were performed using a digital caliper to the nearest $0.1 \mathrm{~mm}$ of precision. The weight was measured using a digital balance with a precision of $0.0001 \mathrm{~g}$. Since the right otolith was cut to provide the age estimates, only the left otoliths were used for the morphometric analysis. 


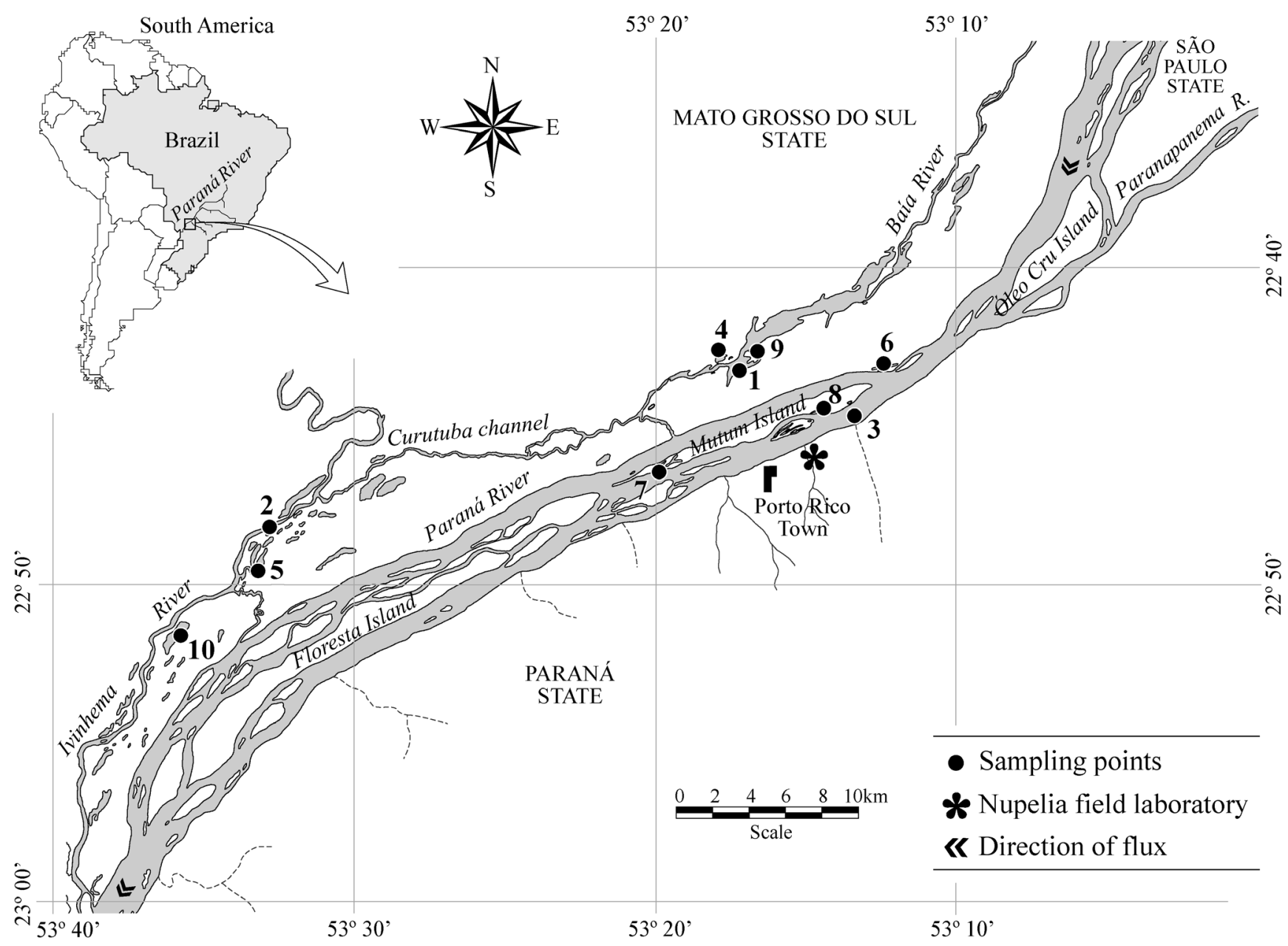

Fig. 1. Study area and location of sampling sites in the floodplain of the Upper Paraná River (Baía River - 1; Ivinhema River - 2; Paraná River - 3; lagoa guaraná - 4; lagoa dos patos - 5; lagoa das garças - 6; lagoa do Osmar - 7; ressaco do paú véio -8 ; lagoa fechada -9 ; lagoa ventura -10 ).

Age determination. The right otoliths were embedded in epoxy acrylic resin and cut using a low-speed Buehler IsoMet hard diamond saw. Three cross-sections were made close to the core of each otolith. The rings (annuli) were counted under transmitted light on a stereoscopic microscope under 40X magnification. The validation and time of formation of the rings were obtained using the increment marginal method proposed by Lai (1987). The marginal increment considers the distances of the last and next to last ring to the edge of the otolith. This metric demonstrated that only one ring is formed annually during the winter, more details about age, growth and validation patterns can be seen in Santana, Minte-Vera (2017). The left otoliths were deposited in the collection of the Growth and Reproduction Laboratory of the Núcleo de Pesquisas em Limnologia, Ictiologia e Aquicultura (Nupélia) in the Universidade Estadual de Maringá (UEM), Paraná, Brazil. Voucher specimens of P. lineatus (NUP 13783) were deposited in the Coleção de Peixes do Núcleo de Pesquisas em Limnologia, Ictiologia e Aquicultura da Universidade Estadual de Maringá.
Data analysis. Pearson correlations were performed to check the degree of association between the lapillus length with lapillus weight. Positive correlations indicate that growth in otolith length is directly associated with the increase of its weight. The lack of correlation indicates that the otolith grows in one dimension, but not in the other.

The relationships among the otolith measurements and both length and weight of the fish were verified using linear regressions. To meet the assumptions of analysis, the fish weight was $\log$ transformed. In all analyses, the otolith measurements were considered predictors for the fish length or weight.

To test whether the length and weight of the otolith differ between the sampled sites, Variance Analysis was performed. However, due to the positive association between fish length and otolith length and weight, the fish length effect was removed (Lleonart et al., 2000). For this, linear regressions between the length and weight of the otolith and the length of the fish were adjusted and, by means of the equations, all otolith measurements were standardized to a standard fish length of $22 \mathrm{~cm}$ (Tab. 1). The value of $22 \mathrm{~cm}$ was chosen because it is a length sampled in all the rivers 
Tab. 1. Equations used and example of how the standardization of the length and weight of the otolith was carried out by removing the effect of the standard length of Prochilodus lineatus. This procedure was done for all observed values. $a=$ angular coefficient; $b=$ intercept.

\begin{tabular}{lccccc}
\hline \multicolumn{1}{c}{ River } & Equation & Observed Value & Predict Value & $\begin{array}{c}\text { Residuals } \\
(\text { Observed }- \text { Predict })\end{array}$ & $\begin{array}{c}\text { Standardized } \\
\text { Value }=(\mathrm{a} * 22)+(\mathrm{b}+\text { residuals })\end{array}$ \\
\hline Baía & $\mathrm{LO}=2.3768+0.0797 * \mathrm{SL}$ & 4.46 & 4.24975 & 0.21025 & 4.32725 \\
Ivinhema & $\mathrm{LO}=2.084+0.0931 * \mathrm{SL}$ & 4.66 & 4.67218 & -0.01218 & 4.12002 \\
Paraná & $\mathrm{LO}=1.8771+0.0988 * \mathrm{SL}$ & 4.46 & 4.2438 & 0.2162 & 4.2185 \\
Baía & $\mathrm{WgO}=0.0004+0.0006 * \mathrm{SL}$ & 0.0139 & 0.0145 & -0.0006 & 0.013 \\
Ivinhema & $\mathrm{WgO}=-0.0043+0.0008 * \mathrm{SL}$ & 0.0217 & 0.01682 & 0.00488 & 0.01818 \\
Paraná & $\mathrm{WgO}=-0.0062+0.0009 * \mathrm{SL}$ & 0.0179 & 0.01585 & 0.00205 & 0.01565 \\
\hline
\end{tabular}

(Baía, Ivinhema and Paraná). The standardized value of otolith length and weight was obtained by regression equations incorporating the residuals (difference between observed and expected measurements) and multiplying the angular coefficient by the adopted standard length $(22 \mathrm{~cm})$. In Tab. 1 is an example of how the measurements were standardized, this procedure was followed for all observed values of otolith length and weight.

Finally, we made analysis of Kruskal-Wallis to verify if the measurements obtained through the otoliths could be used to distinguish the age of the fish. In these analyses, age was considered as a factor and the length and weight were the response variables. All analyses were performed using the R software (R Core Team, 2017) and the adopted level of significance was $\mathrm{p}<0.05$.

\section{Results}

Otolith morphology and morphometry. The lapillus otolith has a wedge-shaped dorsal body, narrowing from the lateral to the medial side, while its posterior region is wider and rectilinear (Fig. 2). Also, the lapillus is a very small otolith; its length is greater than its width (Tab. 2). Their length ranged from 2.03 to $5.95 \mathrm{~mm}($ mean $=4.20 \pm 0.57 \mathrm{SD})$ and the weight from 0.0016 to $0.0484 \mathrm{~g}$ (mean $=0.015 \pm 0.005$ $\mathrm{SD})$. We found a positive correlation between the length and weight of the otolith $(r=0.93)$ indicating that the otolith has a uniform growth in length and weight dimensions.

Tab. 2. Range of the measurements observed in the lapillus otoliths of Prochilodus lineatus. Otolith Length, Otolith Width and Otolith Weight. SD = standard deviation.

\begin{tabular}{lcc}
\hline & Range & Mean \pm SD \\
\hline Length & $2.03-5.95$ & $4.2 \pm 0.57(\mathrm{~mm})$ \\
\hline Width & $1.36-3.98$ & $2.84 \pm 0.38(\mathrm{~mm})$ \\
Weight & $0.0016-0.0484$ & $0.015 \pm 0.005(\mathrm{~g})$ \\
\hline
\end{tabular}

Using the measurements of otoliths as predictors for length, weight and age of the fish. Regression analysis using the otolith measurements as predictors of standard fish length indicated that there is a positive relationship between the length and weight of otolith and the standard length of the

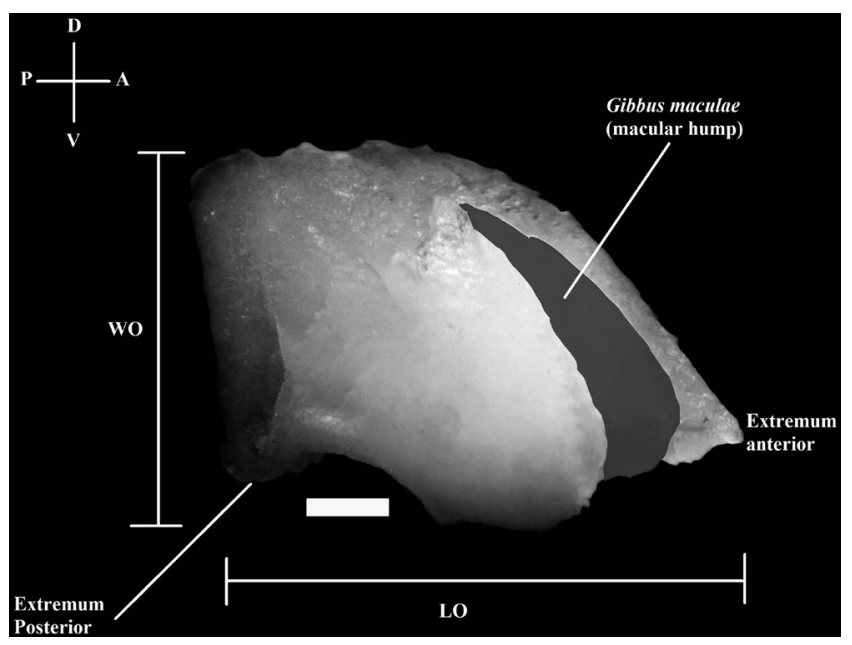

Fig. 2. Lapillus otolith images of Prochilodus lineatus from a scanning electron microscope with $40 \mathrm{X}$ magnification. LO - otolith length; WO - otolith width; the white bar scale is equal to $1 \mathrm{~mm}$. V - Ventral; D - Dorsal, P - Posterior; A Anterior; the highlighted region (grey region - highlighted digitally) is the macular hump.

fish. Otolith's weight is slightly better to predict the length of the fish $\left(r^{2}=0.82\right)$ than the otolith's length $\left(r^{2}=0.80\right)$ (Fig. 3).

The length and weight of the otolith were also good predictors of the weight's fish (Fig. 4). However, the length of the otolith was better adjusted to the smaller fish, so that when the otolith weight was used, it was evident that the fit overestimated the values for the smaller fish.

The length and weight of the otolith were efficient to distinguish the Paraná River from the other two rivers sampled (Baía and Ivinhema), however, in both cases there was no difference between the Baía and Ivinhema rivers. Our analyses indicate that the otoliths of the fish caught in the Paraná River are smaller and lighter than the otoliths caught in the other two rivers (Fig. 5).

Age estimates were made by counting the age rings present in lapillus otolith ranging from 2 to 7 years (ages 2 and 7 were not included in the analysis because they have only one individual). Through analysis of the marginal increment in otolith it was confirmed that only one annual ring is formed in the period from June to August. 

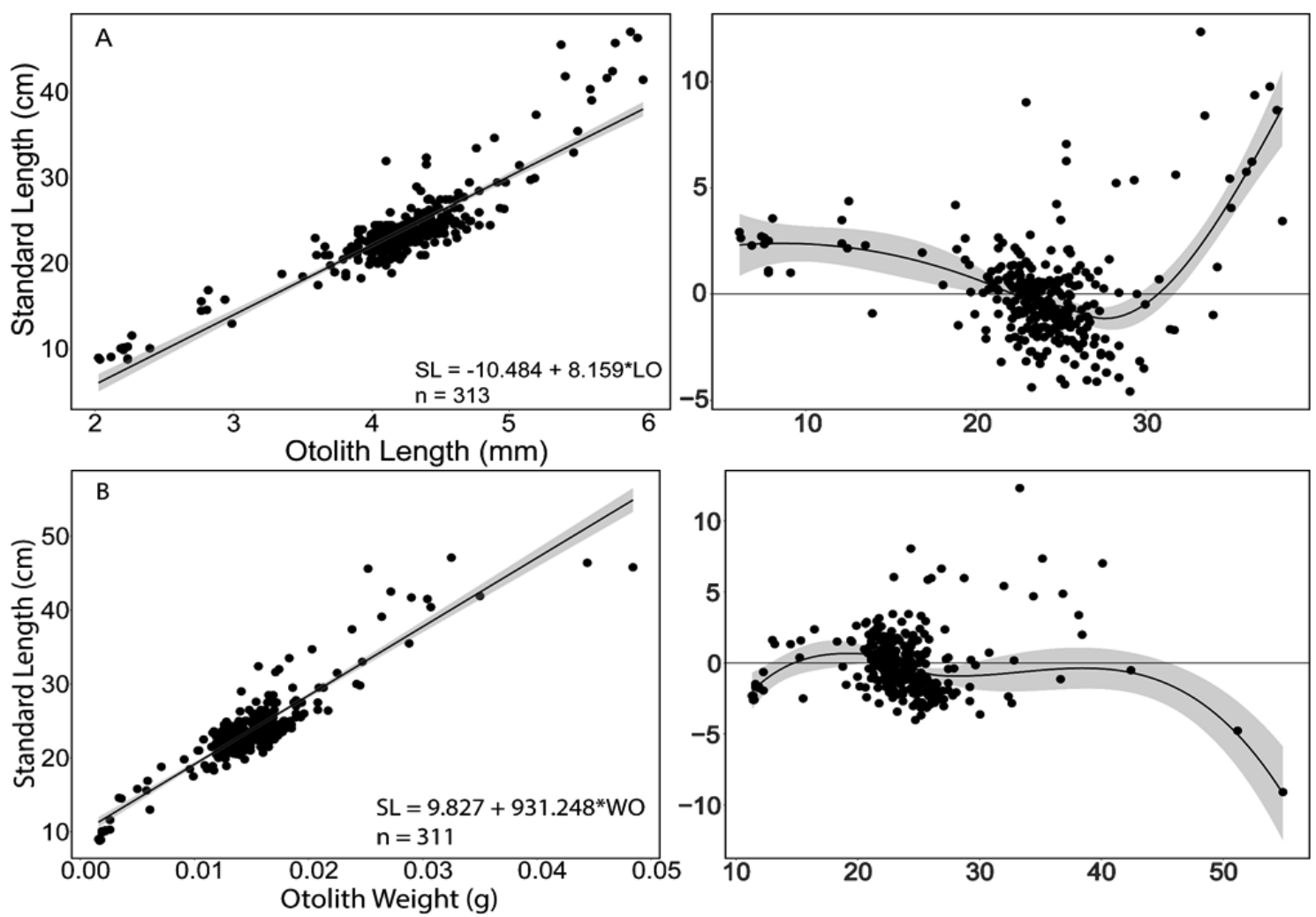

Fig. 3. Fits of the linear regressions between lapillus otolith and standard length of Prochilodus lineatus: a. Otolith Length $\left(r^{2}=0.80\right)$ and $\mathbf{b}$. Otolith Weight $\left(r^{2}=0.82\right)$; the shaded area represents the confidence interval of $95 \%$ of the estimate; loess fit of raw residuals are in right panels.
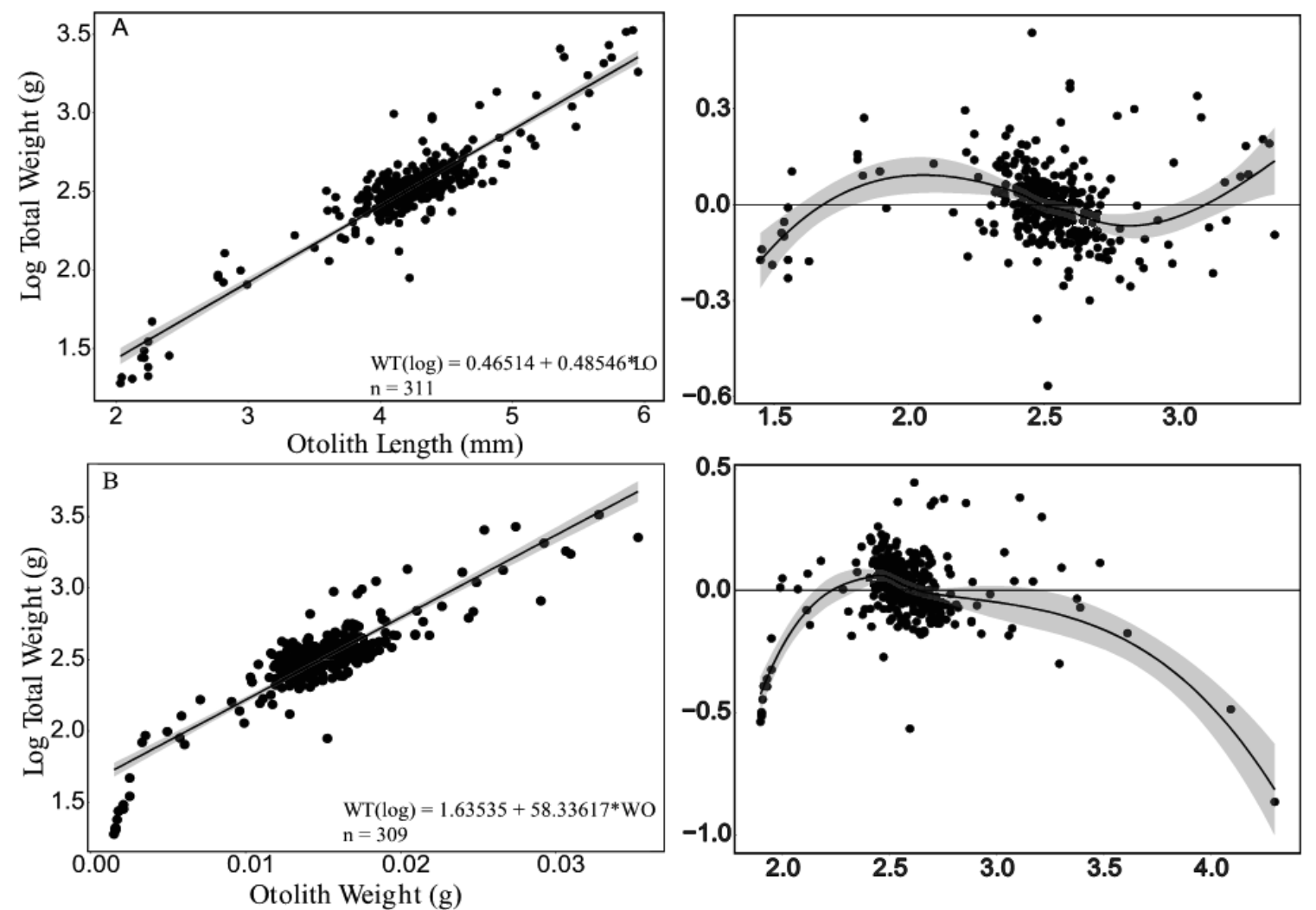

Fig. 4. Fits between lapillus otolith measures and the weight of Prochilodus lineatus: a. Otolith Length $\left(\mathrm{r}^{2}=0.85\right)$ and $\mathbf{b}$. Otolith Weight $\left(r^{2}=0.78\right)$; the shaded area represents the confidence interval of $95 \%$ of the estimate; loess fit of raw residuals are in right panels. 

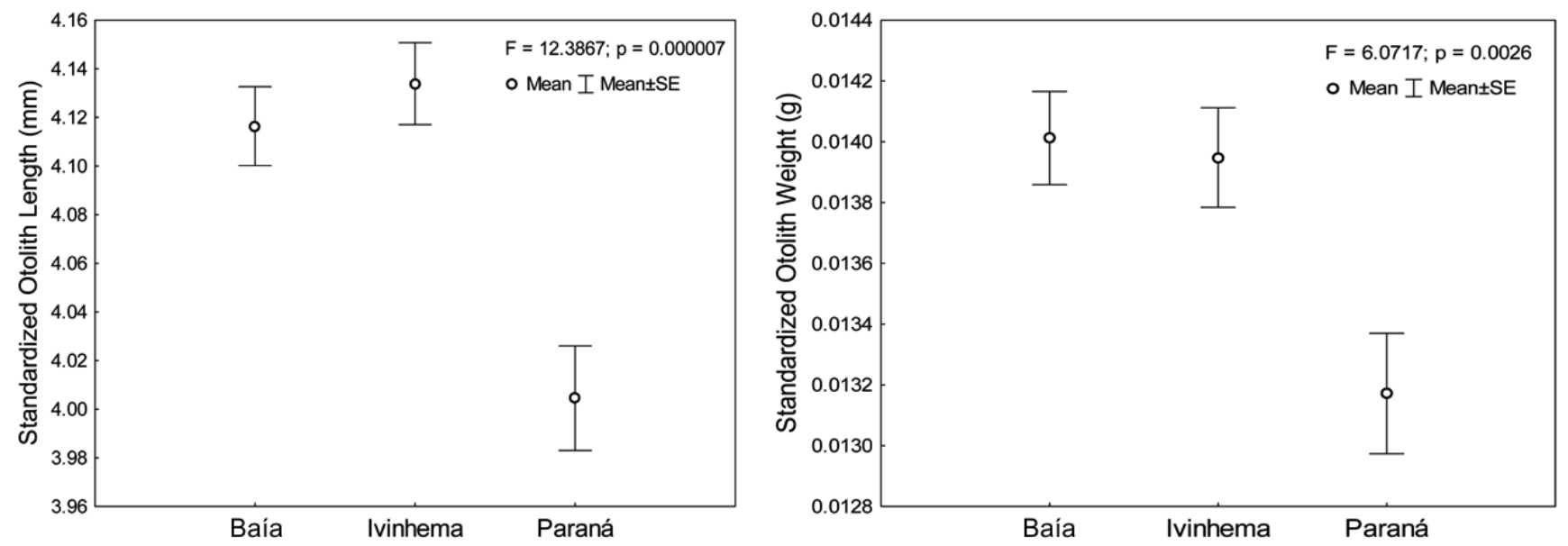

Fig. 5. Analysis of variance between the length and weight of otolith of Prochilodus lineatus in the three rivers sampled (Baía, Ivinhema and Paraná).

Despite the success in predicting the length and weight of the fish using the otolith measurements, the relationship between the age of the fish and these variables does not have the same pattern. Analysis of variance performed between the length and weight of the otolith and the age obtained by the same individual were significant (Fig. 6). However, we note that the standard error range is similar for ages 3,4 and 5 , precluding the prediction of these ages through their respective measures of otoliths. The Tukey test indicated that only fish with six years of age can be easily categorized, but the weight of the otolith seems more effective than otolith length.

\section{Discussion}

Here, we demonstrate that the length and weight of the otolith are good proxies to predict the length and weight of the fish (the otolith length was the best variable explaining the variance of fish length), a fact corroborated by Megalofonou (2006). This result has two main implications: in diet studies (Waessle et al., 2003), once the otoliths are found well preserved in stomach contents, it is possible to predict the size of the prey that was eaten by the predator with a high degree of reliability; and in fossil studies, the size and shape of otoliths provide evidence for the diversity and size of extinct fish (Reichenbacher et al., 2007).

Together, the morphology and morphometry of the otoliths can provide a lot of information, especially on the ecology of $P$. lineatus. Dei Tos et al. (2010) performed a review of age and growth of freshwater fish in South America and concluded that most studies used scales to make the reading of growth rings. Currently the use of otoliths in freshwater studies have increased (Silva, Stewart 2006; Lopez Cazorla, Sidorkewicj, 2011; Lozano et al., 2014). For example, one otolith atlas of Brazilian freshwater fish with relevant information was recently published (Breem, Schulz, 2014). Nevertheless, age and growth studies of freshwater fish using otoliths are still in the process of consolidation and far from stage of similar studies for marine species.
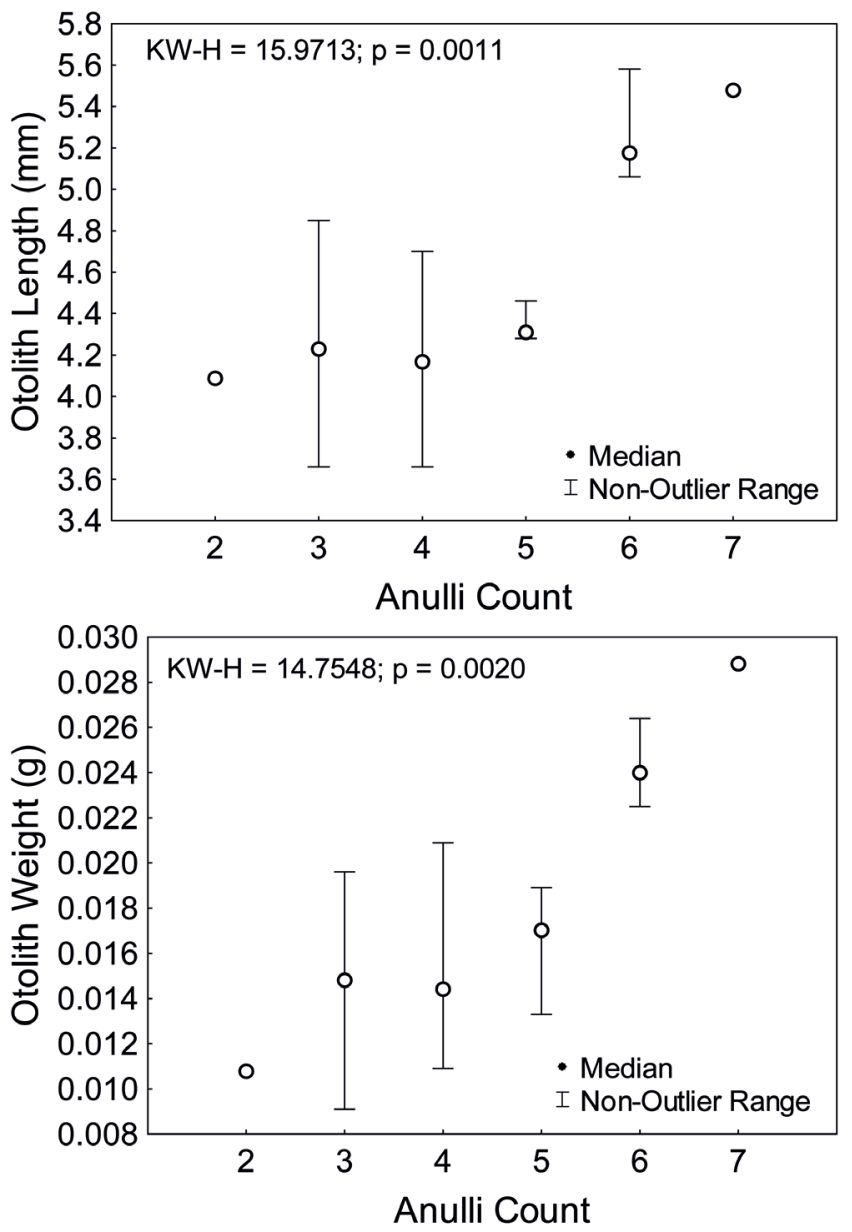

Fig. 6. Kruskall-Wallis results of the lapillus length and weight in each Prochilodus lineatus age; ages 2 and 7 were not included in analysis because they only have one sample.

The morphometry of otoliths has often been used to make predictions about the length, age and weight of fish (Chris-Francis, Campana, 2004; Ilkyaz et al., 2011; Matić -Skoko et al., 2011). Jawad et al. (2011) claim that, in some 
cases, is possible that otolith weight can fits better to fish length because the otoliths stop growing in length when the fish reaches its maximum length. So, once the fish reaches its asymptotic length, the otolith mainly increases in weight and thickness.

Assis (2005), in his extensive discussion of the morphology of the lapillus otolith, notes that there are two main types of otolith: those from clupeiform fishes and those from non-clupeiform fishes. The lapillus otolith of $P$. lineatus belongs to the second group, which is characterized by a remarkable gibbus maculae and a dorsal shaped body. This otolith has a regular shape and generally very similar across many species, a fact that complicates their use in taxonomic studies. It is a very resistant otolith and is easily manipulated and extracted.

The length and weight of the otolith were sufficient to differentiate fish from the Paraná River from the Baía and Ivinhema rivers. As Reynalte-Tataje et al. (2013) point out, the Ivinhema River is one of the main tributaries of the Paraná River along its floodplain and this river is a natural nursery and a great breeding site for migratory species, which has a wide diversity of habitats, availability of food and little fishing pressure, since it is an environmental park.

These characteristics explain the greater weight and length of the otoliths of this river in relation to the otoliths of the Paraná River, since fish from the Paraná River probably grow faster due to both environmental pressures (competition and predation) and anthropic pressures, such as fishing and changes in river flow (Agostinho et al., 2004; Okada et al., 2005). Still, several authors (Walls et al., 1990; Meekan, Fortier, 1996; Enberg et al., 2011) have shown that faster growth can be an evolutionary response since growing faster implies "escaping" from high mortality rates in the early stages of life and maximize survivorship and reproduction.

Once age estimates are fundamental to studies of stocks assessments, population dynamics and growth (Campana, Thorrold, 2001), we highlight that the use of otolith morphometry to make age predictions should be further investigated and, if possible, more used. The use of morphometry of the otolith in age and growth studies can reduce costs and time necessary to produce good information, so that continuous monitoring programs and stock assessments can use this information to improve its effectiveness.

The use of morphometry of the otolith as the fish age predictor is only one alternative to the traditional and already well-studied techniques that involve the processing of otoliths. Obviously, this methodology does not replace the other, but comes as a great alternative to complement and enhance the work with freshwater species. Here we test the differences between the age of fish using length and weight and found that there is high overlap between the measures, especially in the initial ages. Although some ages were statistically different, this result does not support the idea that the age of the fish can be accurately inferred only using these measures.
We propose as directions for future works, studies should focus on better understanding the otoliths and producing databases of morphological and morphometric information. Examples of marine biology should be followed, particularly aiming to provide more information regarding all species. Indirect methods for age estimation should be used with caution because of the inaccuracies and biases associated with the method and, the results presented here are fundamental to the advancement of studies of age and growth in South America, mainly because it is a species with large commercial interest that has suffered great pressure and population reductions.

\section{Acknowledgments}

We thank the Coordenação de Aperfeiçoamento de Pessoal de nível Superior (CAPES) for financial support (Finance Code 001) and NUPÉLIA (Núcleo de Pesquisas em Limnologia, Ictiologia e Aquicultura) for logistical support. We are very grateful to Dr. Steven Campana for contributions and advice and also to the Complexo de Centrais de Apoio à Pesquisa da Universidade Estadual de Maringá (UEM) for its help in using the scanning electron microscope. We also thank the anonymous reviewers and editors for valuable comments that improved the manuscript.

\section{References}

Agostinho AA, Thomaz SM, Minte-Vera CV, Winemiller KO. Biodiversity in the high Paraná River floodplain. In: Gopal B, Junk WJ, Davis JA, editors. Biodiversity in wetlands: assessment, function and conservation. Leiden, Backhuys Publishers; 2000. p.89-118.

Agostinho AA, Gomes LC, Veríssimo S, Okada EK. Flood regime, dam regulation and fish in the Upper Paraná River: effects on assemblage attributes, reproduction and recruitment. Rev Fish Biol Fisher. 2004; 14(1):11-9.

Agostinho AA, Gomes LC, Pelicice FM. Ecologia e manejo de recursos pesqueiros em reservatórios do Brasil. EDUEM, Maringá, 2007.

Assis CA. The utricular otoliths, lapilli, of teleosts: their morphology and relevance for species identification and systematics studies. Sci Mar. 2005; 69(2):259-73.

Baigún C, Minotti P, Oldani N. Assessment of sábalo (Prochilodus lineatus) fisheries in the lower Paraná River basin (Argentina) based on hydrological, biological, and fishery indicators. Neotrop Ichthyol. 2013; 11(1):199-210.

Barletta M, Jaureguizar AJ, Baigun C, Fontoura NF, Agostinho AA, Almeida-Val VMF, Val AL, Torres RA, Jimenes-Segura LF, Giarrizzo T, Fabré NN, Batista VS, Lasso C, Taphorn DC, Costa MF, Chaves PT, Vieira JP, Corrêa MFM. Fish and aquatic habitat conservation in South America: a continental overview with emphasis on neotropical systems. J Fish Biol. 2010; 76(9):2118-76.

Battaglia P, Malara D, Romeo T, Andaloro F. Relationships between otolith size and fish size in some mesopelagic and bathypelagic species from the Mediterranean Sea (Strait of Messina, Italy). Sci Mar. 2010; 74(2):605-12.

Breem CQ, Schulz UH. Otolith atlas of fish of the Sinos River. Braz J Biol. 2014; 74(2):274-82. 
Campana SE, Chouinard GA, Hanson JM, Fréchet A. Mixing and migration of overwintering Atlantic cod (Gadus morhua) stocks near the mouth of the Gulf of St. Lawrence. Can J Fish Aquat Sci. 1999; 56(10):1873-81.

Campana SE, Thorrold SR. Otoliths, increments, and elements: keys to a comprehensive understanding of fish populations? Can J Fish Aquat Sci. 2001; 58(1):30-8.

Chris-Francis RIC, Campana SE. Inferring age from otolith measurements: a review and a new approach. Can J Fish Aquat Sci. 2004; 61(7):1269-84.

Chris-Francis RIC, Harley SJ, Campana SE, Doering-Arjes P. Use of otolith weight in length-mediated estimation of proportions at age. Mar Freshwater Res. 2005; 56(5):735-43.

Dei Tos C, Gomes LC, Ambrósio AM, Goulart E. An overview of freshwater fish aging in South America: the science, biases and future directions. Acta Sci Biol Sci. 2010; 32(4):323-33.

Enberg K, Jørgensen C, Dunlop ES, Varpe Ø, Boukal DS, Baulier L, Eliassen S, Heino M. Fishing-induced evolution of growth: concepts, mechanisms and the empirical evidence. Mar Ecol. 2011; 33(1):1-25.

Fitch JE, Brownell Jr RL. Fish otoliths in cetacean stomachs and their importance in interpreting feeding habits. J Fish Res Board Can. 1968; 25(12):2561-74.

Fontes-Júnior HM, Castro-Santos T, Makrakis S, Gomes LC, Latini JD. A barrier to upstream migration in the fish passage of Itaipu Dam (Canal da Piracema), Paraná River basin. Neotrop Ichthyol. 2012; 10(4):697-704.

Gomes LC, Agostinho AA. Influence of the flooding regime on the nutritional state and juvenile recruitment of the curimba, Prochilodus scrofa, Steindachner, in upper Paraná River, Brazil. Fish Manage Ecol. 1997; 4(4):263-74.

Harvey B, Carolsfeld J. Introduction: fishes of the floods. In: Carolsfeld J, Harvey B, Ross C, Baer A, editors. Migratory fishes of South America: Biology, fisheries and conservation status. Victoria: The International Bank for Reconstruction and Development IDRC/The World Bank; 2003. p.1-18.

Humston R, Moore M, Wass C, Dennis D, Doss S. Correlations between body length and otolith size in smallmouth bass Micropterus dolomieu Lacépède, 1802 with implications for retrospective growth analyses. J Appl Ichthyol. 2015; 31(5):883-87.

Ilkyaz AT, Metin G, Kinacigil HT. The use of otolith length and weight measurements in age estimations of three Gobiidae species (Deltentosteus quadrimaculatus, Gobius niger, and Lesueurigobius friesii). Turk J Zool. 2011; 35(6):819-27.

Iwaszkiw JM, Lacoste FF. La pesca artesanal en la Cuenca del Plata (Argentina) y sus implicancias en la conservacíon de la biodiversidad. Rev Mus Argent Cienc Nat. 2011; 13(1):21-5.

Jawad LA, Ambuali A, Al-Mamry JM, Al-Busaidi HK. Relationships between fish length and otolith length, width and weight of the indian mackerel Rastrelliger kanagurta (Cuvier, 1817) collected from the sea of Oman. Ribarstvo. 2011; 69(2): 51-61.

Lai HL, Gunderson DR, Low LL. Age determination of Pacific cod Gadus macrocephalus, using five ageing methods. Fish Bull. 1987; 85(4):713-23.

Lleonart J, Salat J, Torres GJ. Removing allometric effects of body size in morphological analysis. J Theor Biol. 2000; 205(1):8593.

Lozano IE, Llamazares Vegh S, Dománico AA, Espinach Ros A. Comparison of scale and otolith age readings for trahira, Hoplias malabaricus (Bloch, 1794), from Paraná River,
Argentina. J Appl Ichthyol. 2014; 30(1):130-34.

Lopez Cazorla A, Sidorkewicj N. Age, growth and reproduction in creole perch (Percichthys trucha) in the Negro River, Argentinean Patagonia. J Appl Ichthyol. 2011; 27(1):30-38.

Matić-Skoko S, Ferri J, ŠkeljoF, Bartulovic V, Glavić K, Glamuzina B. Age, growth and validation of otolith morphometrics as predictors of age in the forkbeard, Phycis phycis (Gadidae). Fish Res. 2011; 112(1-2):52-8.

Meekan MG, Fortier L. Selection for fast growth during the larval life of Atlantic cod Gadus morhua on the Scotian Shelf. Mar Ecol Prog Ser. 1996; 137:25-37.

Megalofonou P. Comparison of otolith growth and morphology with somatic growth and age in young-of-the-year bluefin tuna. J Fish Biol. 2006; 68(6):1867-78.

Okada EK, Agostinho AA, Gomes LC. Spatial and temporal gradients in artisanal fisheries of a large Neotropical reservoir, the Itaipu Reservoir, Brazil. Can J Fish Aquat Sci. 2005; 62(3):714-24.

Radhakrishnan KV, Yuxuan L, Jayalakshmy KV, Ming L, Murphy $\mathrm{BR}$, Songguang X. Application of otolith shape analysis in identifying different ecotypes of Coilia ectenes in the Yangtze Basin, China. Fish Res. 2012; 125-126:156-60.

$\mathrm{R}$ Core Team. A language and environment for statistical compunting. R Foundation for Statistical Computing, Vienna, Austria. Available from http://www.R-project.org/, 2017.

Reichenbacher B, Sienknecht U, Küchenhoff H, Fenske N. Combined otolith morphology and morphometry for assessing taxonomy and diversity in fossil and extant killifish (Aphanius, Prolebias). J Morphol. 2007; 268(10):898-915.

Reynalte-Tataje DA, Agostinho AA, Bialetzki A. Temporal and spatial distribution of the fish larval assemblages of the Ivinheima River sub-basin (Brazil). Environ Biol Fishes. 2013; 96(7):811-22.

Secor, DH, Dean JM, Laban EH. Manual for otolith removal and preparation for microstructural examination. Columbia: Baruch Institute Technical Report; 1991.

Santana HS, Minte-Vera CV. Age and growth of Prochilodus lineatus in a spatially structured population: is there concordance between otoliths and scales? Environ Biol Fishes. 2017; 100(3):223-35.

Silva EA, Stewart DJ. Age structure, growth and survival rates of the commercial fish Prochilodus nigricans (bocachico) in North-eastern Ecuador. Environ Biol Fishes. 2006; 77(1):6377.

Škeljo F, Ferri J. The use of otolith shape and morphometry for identification and size-estimation of five wrasse species in predador-prey studies. J Appl Ichthyol. 2012; 28(4):524-30.

Tuset VM, Lombarte A, Assis CA. Otolith atlas for the western Mediterranean, north and central eastern Atlantic. Sci Mar. 2008; 72(S1): 7-198.

VanderKooy S, Guindon-Tisdel K. A practical handbook for determining the ages of Gulf of Mexico fishes. Ocean Springs: Gulf State Marine Fisheries Commission; 2003. (Gulf States Marine Fisheries Commission; No 111).

Van Neer W, Ervynck A, Bolle LJ, Millner RS, Rijnsdorp AD. Fish otoliths and their relevance to archaeology: an analysis of Medieval, Post-Medieval, and Recent Material of Plaice, Cod and Haddock from the North Sea. Environ Archaeol. 2002; 7(1):61-76.

Waessle JA, Lasta CA, Favero M. Otolith morphology and body size relationships for juvenile Sciaenidae in the Río de la Plata estuary (35-36 ${ }^{\circ}$ S). Sci Mar. 2003; 67(2):233-40. 
Walls M, Kortelainen I, Sarvala J. Prey responses to fish predation in freshwater communities. Ann Zool Fenn. 1990; 27(2):18399.

Welcomme RL. Fisheries ecology of floodplain rivers. New York: Logman Inc; 1979.

Zan XX, Zhang C, Xu BD, Zhang CL. Relationships between fish size and otolith measurements for 33 fish species caught by bottom trawl in Haizhou Bay, China. J Appl Ichthyol. 2015; 31(3):544-48.

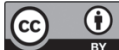

Submitted July 26, 2018

Accepted August 21, 2018 by Franco Teixeira de Mello 